\title{
Economic Inequality among Districts in Keerom, Papua, Indonesia
}

\author{
Nuralam, Suwandi \\ Cendrawasih University Jayapura Papua, Indonesia \\ wandi1212@gmail.com
}

\begin{abstract}
This research described about economics growth and economic imbalance among districts in Keerom regency. The aim of this research is (i) to explain the pattern of economics growth per district in Keerom regency (ii) to illustrate the imbalance among districts in Keerom regency (iii) to examine Kuznets hypothesis about the Inverted of $U$ in Keerom regency. Analysis technique has been applied is Klassen typology, Williamson's index and Pearson's correlation. In this research, Klassen typology is divided by two quadrants. The result of this research showed the low of Williamson's index and there was not applicable result on analysis with the Inverted of $U$ by Kuzrets hypothesis. This research is expected to be a useful input for government, particularly for local government of Keerom regency.
\end{abstract}

Keywords: Economic growth, imbalance among districts, Keerom regency

\section{Introduction}

Background: Economics development in an area is a process of development in a community with its government in managing the available resource and to form a pattern of partnerships with private sectors to create a new job and stimulate economic growth on the area. The difference of material and human resources may imply on the model of the development plan. If the policy is implemented in one area, is not always suitable in another area, depends on its natural and human resources and how to access it, so there is an essential of regional plan for every area (Arsyad, 1999). Keerom regency is directly adjacent to the neighboring country of Papua New Guinea (PNG). It is nearby the heart of Keerom city $( \pm 50$ $\mathrm{km}$ ).Transportation from and to Keerom is quiet easy, except some districts such as Waris and Senggi have lack of infrastructure. Similarly, the furthest district is Touwe which should use Cesna airplane to reach it. The expansion is intended to shorten the public service bureaucracy so the public service can be affordable. Basically, the idea of expansion is very noble, but in its implementation should be scrutinized even doubtful, because the reality shows after the expansion, public service is still running in place. In fact, Papuan people are lack of service and development.

In Keerom, after over ten years of expansion, there has not been a positive impact on community development, especially for the Papuan people, who live in the regency. Say, the Papuan people are even more marginalized as it is invisible at the lives of native people of Papua, which are located on the outskirts of the center of government Keerom, such as Kampung Arso and Workwana, which the people are very far from welfare. There are many examples of inequality of development and services in the areas of health, education, economy, housing and others that show impartiality of Papuan government towards native Papuan. Apparently the government is more interested in doing development and improvement of infrastructure in urban areas, which are controlled by immigrants rather than doing development in villages inhabited by native Papuan. If the pattern of such development is not addressed, it will cause a deep gap between the Papuan people with immigrants. Papuan people will be impoverished in their own land, while the immigrants will live in prosperity. If this social inequality is available, it is certainly there will be a time of social friction that will hurt many parties.

The problem can be solved if the government has willing to protect the Papuan people. Until now, there has been no policy to provide special protection for Papuan people of Keerom. They were eliminated in the midst of the development in Keerom and the question is coming:"Development in Keerom for whom? Only for the immigrants? Where the space for indigenous of Papuan people place of the specificity of the Papuan people? 
"It is sorry for any inaccuracies development and services which is less balanced between Papuan people with the immigrants. In fact, in the era of special autonomy in Papua, Papuan people should receive serious attention in all aspects of service. Instead of creating social envy, but for the sake of protection, as mandated by the Special Autonomy of Papua. Based on the background of the issues that have been mentioned, the issues raised is how to increase the level of income from inequality among districts in Keerom, what is the relationship between inequality index and GDP growth in Keerom form through an inverted U-shaped pattern.

Basic of the Theory: The theory has been utilized is historical economic growth theory and the theory of classical and neoclassical economic growth. Historical flow grows in Germany and is a reaction to the classical view that states economic growth can be accelerated with the industrial revolution, while the historical flow states that economic growth is done in stages. The pioneers of historical flow are Frederich List, Karl Bucher, Bruno Hildebrand, Wegner Sombart, and WW Rostow (Suwandi \& warokka, 2013). Kusnetz in Sukirno (2004) defines economic growth as a change and the ability of a country to provide economic goods for its people. The level of a country's ability to provide economic goods for the population due to advances in technology, institutional and ideological adjustments. According to Rostow and Hirschman in Kapisa et al. (2013), there is a concept of unbalanced growth. Hirchman has understanding that development should not be balanced. The development occurs because there is a sector is growing faster than other sectors. The new sector, with the hope of meeting the demand for the previous sector, is growing more rapidly over the original sector, and so on. Inequality in the distribution of income is the imbalance in economic development among various regions in an area that will lead to inequality in per capita income levels among areas. The analysis to calculate regional inequality is using inequality index of Williamson and Theil inequality index (Kuncoro, 2004).

Williamson in Kuncoro (2004) explained that inequality gap among regions are growing due to: first, the presence of inter-regional labor migration is treated in selective and particularly the migrants are more educated, have a high enough skill, and still productive. Second, the existence of capital migration among regions, the process of agglomeration in other areas resulting in the flow of capital to areas that have already developed first. Third, the construction of public facilities in a more populated area and potentially result in encouraging greater inter-regional imbalance. Fourth, the lack of linkages among regions can lead to obstruction of the dispersive effects of the development process which impact on the magnitude of the gap / inequality (Martapina, Suwandi \& Warokka, 2013). Kusnetz in Sukirno (2004) who pioneered the analysis of historical patterns of growth in developed countries explained that the first stage of economic growth, income distribution tends to deteriorate, but at a later stage, the distribution of income will be improved. This observation is widely known as the concept of the curve "inverted-U", because changes in the longitudinal (time series) in income distribution decreases with an increase in GNP per capita in the next stage of development.

\section{Methodology}

Research Location: Location of the research was conducted in Keerom because previously there has been no study on the economic growth and inequality among districts in Keerom. Previous similar studies have not been available, causing a gap for the government of Keerom information. This research is very important as a material consideration in formulating policies related to economic growth in each district.

Data Sources: This research used secondary data as data has processed further by collecting primary data and from other parties. Secondary data in this study is the value of GDP Keerom, the value of GDP per district in Keerom, and the number of inhabitants per district in Keerom 2008-2012.

\section{Data Analysis}

Klassen's Typology: This analysis used to determine the image of the pattern and structure of economic growth of areas as some studies use this analysis to determine the structure of economic growth. This tool is 
used to obtain the classification of regional economic growth, while data is pace of economic growth and income per capita. Formulation analysis tools can be seen in Table I below:

Table 1: Classification of Economics Growth by Klassen's Typology

\begin{tabular}{lll}
\hline $\begin{array}{l}\text { Income per Capita } \\
\text { (Y) } \\
\text { Growth's rate (r) }\end{array}$ & ydi $>$ yni (+) & ydi $<$ yni (-) \\
\hline rdi $>$ rni (+) & $\begin{array}{l}\text { This area is advanced and rapidly } \\
\text { growing }\end{array}$ & $\begin{array}{l}\text { The area is growing fast but not } \\
\text { developed }\end{array}$ \\
rdi $>$ rni (-) & Developed regions but depressed & Relatively underdeveloped regions \\
\hline
\end{tabular}

Williamson's Index: The analytical tool used to determine the development imbalance among districts that occur in Keerom, using an index of regional inequality (regional inequality) are called index Inequality Williamson. Kuncoro in Fajar (2009) took the formula as follows:

$$
\mathrm{IW}=\frac{\sqrt{\sum(\mathrm{Yi}-\mathrm{y}) 2 \mathrm{fi}-\mathrm{n}}}{\mathrm{Y}}
$$

Where:

Yi : income per capita each district of $\mathrm{i}$

y : : income per capita of Keerom regency

fi : population of i district

n : population of Keerom regency

Index formula Williamson is utilized income per capita and population, and the number is between 0 and the real number $(0<\mathrm{IW}<\mathrm{l})$. When the number is approaching 1 , it means giving indicator of large regional imbalances and vice versa when the number of index value obtained is close to zero then it indicates the regional imbalance is small or very uneven.

Pearson Correlation: Pearson's correlation can be seen from the significant value if positive or negative correlation forms. If the relationship is two variables showed a correlation value is less or more than zero (0), if it showed no correlation, the value is zero (0). Positive correlation value means the direction of the relationship between one variable with another variables is one-way, in other words, there was an increase of GDP growth. Then the increase will affect the level of regional income gap (Kuncoro, 2004). The results of this analysis Pearson's correlation used to determine the relationship among income per capita by Williamson's index.

Kuznets's theory of the Inverse of U: Kusnetz, who pioneered the analysis of historical growth patterns in developed countries, suggests that in the early stages of economic growth, income distribution tends to deteriorate, but at a later stage, the distribution of earnings will improve. This observation is widely known as the concept of the curve "U-inverted," because longitudinal changes in line with the increase of distribution of income will decline in GNP per capita on further development stage. Short-term downturn in the growth of income per capita often ends in inequalities. Hypothesis of Kusnet (inverted U curve) can be proved by making GDP per capita and inequality index. The inverted $U$ is a relationship between GDP growth and the Theil entropy index, in this case, during the observation period. "Inverted U-curve" illustrates the distribution of income inequality increased in the early stages of development and decline in subsequent stages (Kuncoro, 2004).

Discussion: Klassen typology analysis is used to acknowledge the structure of economic growth among districts in Keerom during 2007-2011. Based on the research result, Klassen Typology of the obtained classification of growth among districts is shown in Keerom as Table 1. Table 2 shows the classification of economic growth in Keerom regency, indicates that nine districts in Keerom can be classified into two areas. 
The first area is fast-growing area but it is not developed districts, consist of five districts namely: Gerokgak, Seririt, Sukasada, Keerom. Next is districts included fast growing areas but it is not included because its GDP per capita is more than GDP per capita of Keerom, and the districts have GDP growth rate is greater than the rate of GDP growth of Keerom.

Table 2: Classification of Economics Growth in Each District in Keerom Regency by Klassen Typology

\begin{tabular}{lll}
\hline & Ydi $>$ yni (+) & Ydi $<$ yni $(-)$ \\
\hline Rdi $>$ rni $(+)$ & $\begin{array}{l}\text { Advanced and fast growing areas : } \\
(-)\end{array}$ & $\begin{array}{l}\text { Fast growing areas but they are not developed : } \\
\text { Arsokota, Skanto, Arsotimur, Senggi } \\
\text { Rdi<rni(-) }\end{array}$ \\
$\begin{array}{l}\text { Advanced area but they are not } \\
\text { developed }\end{array}$ & $\begin{array}{l}\text { Areas Relatively disadvantage: Web, Towe, } \\
\text { Waris. }\end{array}$ \\
\hline
\end{tabular}

Source: KlassenTypology with processed

The second area that is relatively underdeveloped regions, districts are included in this classification are those having GDP per capita smaller than GDP per capita of Keerom, and the district GDP growth rate is lower than the rate of GDP growth in Keerom. Those are Web, Towe, Waris. The numbers of the income inequality among districts provide an overview of the condition and development in Keerom. The development of regions will be discussed on equalization GDP per capita of Keerom. All districts were analyzed using Williamson's index. This index is the dispersion coefficient index of the average value on distribution, which is calculated based on the estimation of the value of GDP and population. They are in the scope of the area studied and analyzed. The results can be seen in Table 3 .

Table 3: Williamson's Index among Districts in Keerom Regency, 2008-2012

\begin{tabular}{lll}
\hline No & Year & Williamson's Index \\
\hline 1 & 2008 & 0,090 \\
2 & 2009 & 0,089 \\
3 & 2010 & 0,072 \\
4 & 2011 & 0,062 \\
5 & 2012 & 0,086 \\
\hline
\end{tabular}

Source: Williamson's index (processed)

Williamson's index number is getting smaller or close to zero indicates that the lesser inequality or in other words the more consistently treated and the further away from zero indicates a widening inequality. This means the more developments have been executed, the more inequity will appear. The index of GDP per capita among districts in Keerom regency are relatively low as well as it approaches zero. Table 3above describes on 2008 Williamson's index was 0.090, on 2009 the index has decreased to be 0.089, and it continued up until 2011 was 0.062 . On 2012, the index increased to reach 0.086 . This indicates that GDP per capita of Keerom regency in average has been getting improved. The relationship between Williamson's index and income per capita can be acquired by Pearson correlation analysis. The result of Pearson's correlation is able to read through significant numbers. Statistical data processing through the Pearson correlation to determine the relationship between income per capita and Williamson's index, getting the result of -0.854 with a significance value of 0.140 which is statistically significant. Pearson's correlation and the relationship is negative showing there is a contrast of correlation.

Table 4: Pearson's correlation analysis result

\begin{tabular}{llll}
\hline & & Williamson's index & Income per capita \\
\hline Willliamson's Index & Pearson's Correlation & 1 & -.854 \\
& Sig. (2-tailed) & & .140 \\
& $\mathrm{~N}$ & 5 & 1 \\
Income per capita & Person's Correlation & -.854 & \\
& Sig (2-tailed) & .140 & 2 \\
\hline
\end{tabular}

Source: Pearson's correlation analysis result (data processed) 
Kuznets' hypothesis in Keerom's regency: Hypothesis Kuznets' hypothesis can be proved by curve showing the relationship between Williamson's index and Income per capita as follows:

\begin{tabular}{lll}
\multicolumn{2}{l}{ Table5: Williamson's Index and Income per capita on Keerom's regency, 2007 - 2011 } \\
\hline Year & Williamson's Index & Income per capita \\
\hline 2008 & 0,090 & $6.722 .250,75$ \\
2009 & 0,089 & $5.821 .477,79$ \\
2010 & 0,072 & $5.598 .677,29$ \\
2011 & 0,062 & $5.667 .260,60$ \\
2012 & 0,086 & $5.865 .377,78$ \\
\hline
\end{tabular}

Source : Williamson's index analysis (data processed)

Table 5 shows the relationship between GDP regional per capita and index of inequality in Keerom regency. The table didn't show "the Inverted U", indicating there was not proven of Kutznets' theory in Keerom regency. This finding is in line with the theory of used by Alesina dan Rodric that good income distribution makes it possible to achieve high economic growth that examines Kuzrets' hypothesis about inequlity by "the Inverted U" curve (Suharto, 2001).

\section{Conclusion}

- By Klassen's typology, Keerom regency can be divided by two area's classification. First areas are rapidly fast growing but they are not developed. These areas are Arsokota, Skanto, Arsotimur, and Senggi. Second areas are districts that relatively left behind. They are: Web, Towe, and Waris. During the observation of $2008-2012$, the numbers of Williamson's index are relatively low, indicates that inequality in Keerom regency is comparatively small

- Kuznets' hypothesis about "the Inverted U" in Keerom regency is not convincing. The relationship between income per capita and Williamson's inequality index is not "Inverted U"; even it is shaped of U.

\section{References}

Arsyad, L. (1999). Introduction to Planning and Regional Economic Development BPFE. Jogyakarta.

Fajar, U. P. (2009). Analysis of Economic Growth and Imbalanced Level in Regencies/Cities Kedungsepur Area, Year 2004-2008. http://eprrints.undip.ac.id/26414/2/JURNAL.pdf. Pukul 00.15Wita Vol. 17 , p.291 - 297.

Kapisa, N., Suwandi. \& Wahyu, A. P. (2013). The Nexus Of Economic Growth, Unemployment, And Poverty: Do Decentralization and Special autonomy Really Matter? ProccedingsOf the 2013. KMITL AGBA Global Conference in Bangkok, Thailand.Juni 15-17

Kuncoro, M. (2004). Autonomy of Local Development. Jakarta: Erlangga.

Martapina, A., Suwandi. \& Warokka, A. (2013). Decentralization And Public Expenditure: Does Special Local Autonomy Affect Regional Economic Growth? ProccedingsOf the 2013. KMITL AGBA Global Conference in Bangkok, Thailand.Juni 15-17 2013.

Sjafrizal. (1997). Economic Growth and Regional Imbalance in West Indonesia Area. Padang: Praninta Offset. Suharto. 2001. Income Distribution on Development. Yogyakarta: Jurnal Ekonomi Pembangunan, 6(1), 5-10

Sukirno, S. (2004). Teori pengantar makroekonomi. Jakarta: PT rajaGrafindo persada.

Sukirno, S. (2004). Introduction to the theory of macroeconomics. Jakarta: PT rajaGrafindo persada.

Suwandi. \& Warokka, A. (2013). Fiscal Decentralization and Special Local Autonomy: Evidence from in Emerging Market. Journal of Southeast Asian Research, 20(13), 4-9. 